\title{
WHAT FUTURE FOR THE LAND OF THE WOODEN CIVILISATION? VERNACULAR ARCHITECTURE FROM MARAMURES AS SUBJECT OF A LONG STANDING DEBATE
}

\author{
Gabriela ILIES ${ }^{*}$ \\ Babes-Bolyai University, Faculty of Geography, Sighetu Marmatiei Extension, \\ Avram Iancu 6, 435500 Sighetu Marmatiei, e-mail: gabriela.ilies@ubbcluj.ro

\section{Marin ILIES} \\ Babes-Bolyai University, Faculty of Geography, Sighetu Marmatiei Extension, \\ Avram Iancu 6, 435500 Sighetu Marmatiei, e-mail: marin.ilies@ubbcluj.ro

\section{Mihai HOTEA} \\ Babes-Bolyai University, Faculty of Geography, Sighetu Marmatiei Extension, \\ Avram Iancu 6, 435500 Sighetu Marmatiei, e-mail: mihai.hotea@ubbcluj.ro
}

\section{Alina Simona SIMION}

Babes-Bolyai University, Faculty of Geography, Sighetu Marmatiei Extension, Avram Iancu 6, 435500 Sighetu Marmatiei, e-mail: simona.simion@ubbcluj.ro

\section{Silviu-Vasile BUMBAK}

Babes-Bolyai University, Faculty of Geography, Sighetu Marmatiei Extension, Avram Iancu 6, 43550o Sighetu Marmatiei, e-mail: silviu.bumbak@ubbcluj.ro

\begin{abstract}
Citation: Ilies, G., Ilies, M., Hotea, M., Simion, A.S., \& Bumbak, S.V. (2018). WHAT FUTURE FOR THE LAND OF THE WOODEN CIVILISATION? VERNACULAR ARCHITECTURE FROM MARAMURES AS SUBJECT OF A LONG STANDING DEBATE. GeoJournal of Tourism and Geosites, 22(2), 585-596. https://doi.org/10.30892/gtg.22226-313
\end{abstract}

\begin{abstract}
Maramures Land is a Romanian historical and ethnographic region known as "the land of the wooden civilisation" due to high concentration of vernacular architecture in wood and remarkable virgin forests. Preservation of the architectural heritage has a long standing history as debate subject: authorities and stakeholders recognise its endangered status and complicated evolving paths. Therefore, this paper looks at the specifics of the discourse regarding vernacular architecture in Maramures - heritage sites and common structures - in order to outline the preservation strategies developed along the last twenty years, focusing on policies, programmes, local initiatives and impact. The main result is a multi-scale analysis on a geo-database with the traditional buildings in the rural area of the region. In addition, the timeline revealed the milestones of the debate on wooden architecture, in respect with two case-studies: UNESCO and a Local Action Group.
\end{abstract}

Key words: Maramures, vernacular architecture, heritage preservation, wooden church, wooden house, wooden gate

\footnotetext{
${ }^{*}$ Corresponding author
} 


\section{INTRODUCTION}

Vernacular architecture from Maramures (Romania) is a well-defined concept, comprising the traditional way of building in wood developed by local masters upon traditional knowledge (Dancus, 2010). This is a subsidiary of the basic definition employed by Brunskill (2000), as the usual way of building in a place, based on climatic constraints and cultural norms. Climatic limitations refer to conditions such as natural setting, type of wood, land use, as well as harvesting season. Cultural norms direct the woodcraft according to the functions of the building. Moreover, there is a set of social status constraints originating from the regions' historical narratives.

Consequently, the rural built landscape evolved with difficulties, determining relevant shifts in the public discourse regarding the conservation state and the appropriate protection plan. Two important characteristics of this evolution path have triggered the debate on the endangered status of the traditional architecture in Maramures: (1) the obvious decrease in number and diversity of new wooden dwellings, and (2) the eventual disappearance of the old wooden houses, demolished or marketed as reclaimed material. In contrast, the number of wooden churches and gates built in Maramures style is raising, being constantly assimilated into common Romanian identity marker. Therefore, this study analyses the specifics of the discourse in order to outline the preservation strategies developed along the last twenty years, with accent on their outcomes: policies, programmes, local initiatives and impact.

\section{MATERIALS AND METHODS}

The main result of the study is a multi-scale analysis. The subsequent geo-database with traditional buildings in the rural area is essential to the development of the research on the conservation state and evolution, while using specific fieldwork tools (spatial data retrieval, photographs, interviews with the main stakeholders and with locals) and GIS (open source Quantum GIS, software for mapping and visualisation). Basic classification and hierarchical clustering operations were applied to the retrieved data, in order to assess the properties with higher cultural value; applying buffering methods and computing several dispersion indexes revealed the areas that needed more attention or, on the contrary, the high density streets suitable for sightseeing products. Research results were then transferred towards the local communities in order to enhance the activities as restoring the authentic aspect of the village, embellishing the facades with woodcraft pieces, funding repairs on the buildings visible on the public domain.

Longitudinal analysis generated a timeline, both comprehensive and relevant for the evolution of the traditional buildings. Firstly, the work package focused on official strategic documents, reports and other online available sources. This allowed the compilation along a timeline with key-moments and shifts. Secondly, a set of unstructured interviews with local stakeholders completed the study, completing the knowledge on the public discourse concerning the vernacular architecture. Nevertheless, full statistical data description does not make the object of this study.

\section{STUDY AREA}

In Romania, the lands are regions with boundaries strongly marked by their historical evolution and ethnographic features. In a more extensive approach, they are regional matrices preserving the archaisms, the traditional way of life, where regional identity and social capital are obvious (Cocean, 1997). Regional researches and reports list 
them as 'countries' due to the strong resemblance to the French term of 'pays' (Claval, 1994), or after their historical name 'tara/terra' in early stage translations (ICOMOS, 1999). There are twenty-one land regions, situated in lowlands around the Carpathian Mountains and Maramures is one of them. Maramures Land located to the north of Romania, on the border with Ukraine, stretches on $331 \mathrm{~km}^{2}$ along the Tisza River and its left side tributaries. Nowadays it is also known as 'the Land of the wooden civilisation' due to its vernacular architecture in wood and remarkable pristine forests. Nevertheless, valuable heritage sites in the area, both natural and historical, made Maramures an important tourist destination, especially for cultural rural tourism (Figure 1).

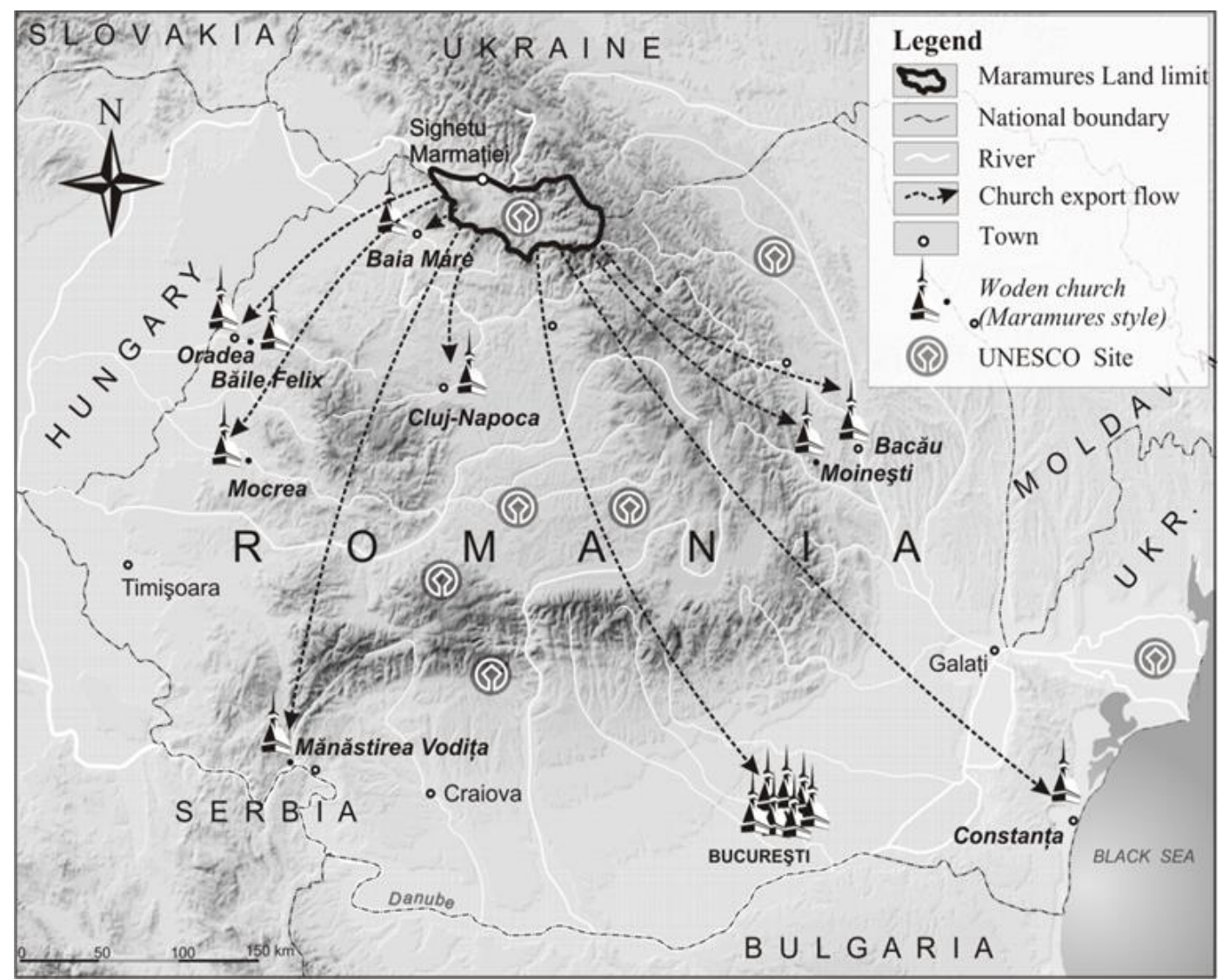

Figure 1. Maramures Land. Location of new wooden churches beyond the region

The traditional built landscape has three distinct functional elements: wooden dwellings, wooden gates and wooden churches. The old constructions dating from the 17th and 18th century coexist with the newest structures constructed in a similar way. Traditional wooden houses are built on simple rectangular plans, with two or three rooms, low ceiling and small windows. The walls are squared logs form oak or pine, depending on the forest nearby, starting from a stone foundation. The high, shingled roof truss has four slopes, at approximately 60o. In front of the house several sculpted pillars support the terrace (Figure 2). Although they are important representatives of the traditional society in the region, heritage protection policies never listed the houses. 
The shape and size of the homes do not depend on the social status of the family, but on the nature of the available material and the legal regulations for timber. In the region there are 63 villages that house 200000 inhabitants, $50 \%$ of which live in wooden buildings according to the 2011 National Census Data (INSSE, 2016). Furthermore, the statistical data do not show the share of the buildings with high cultural value, as described by ethnographers and other relevant voices in the field, leaving the ground for extensive research. Wooden gates in Maramures are monumental structures that mark the entrance not only into the private realm of a family, but also on important symbolical properties as churches, schools, town halls and other. Important visual elements comprise the scale, the material and decorations (Figure 2).

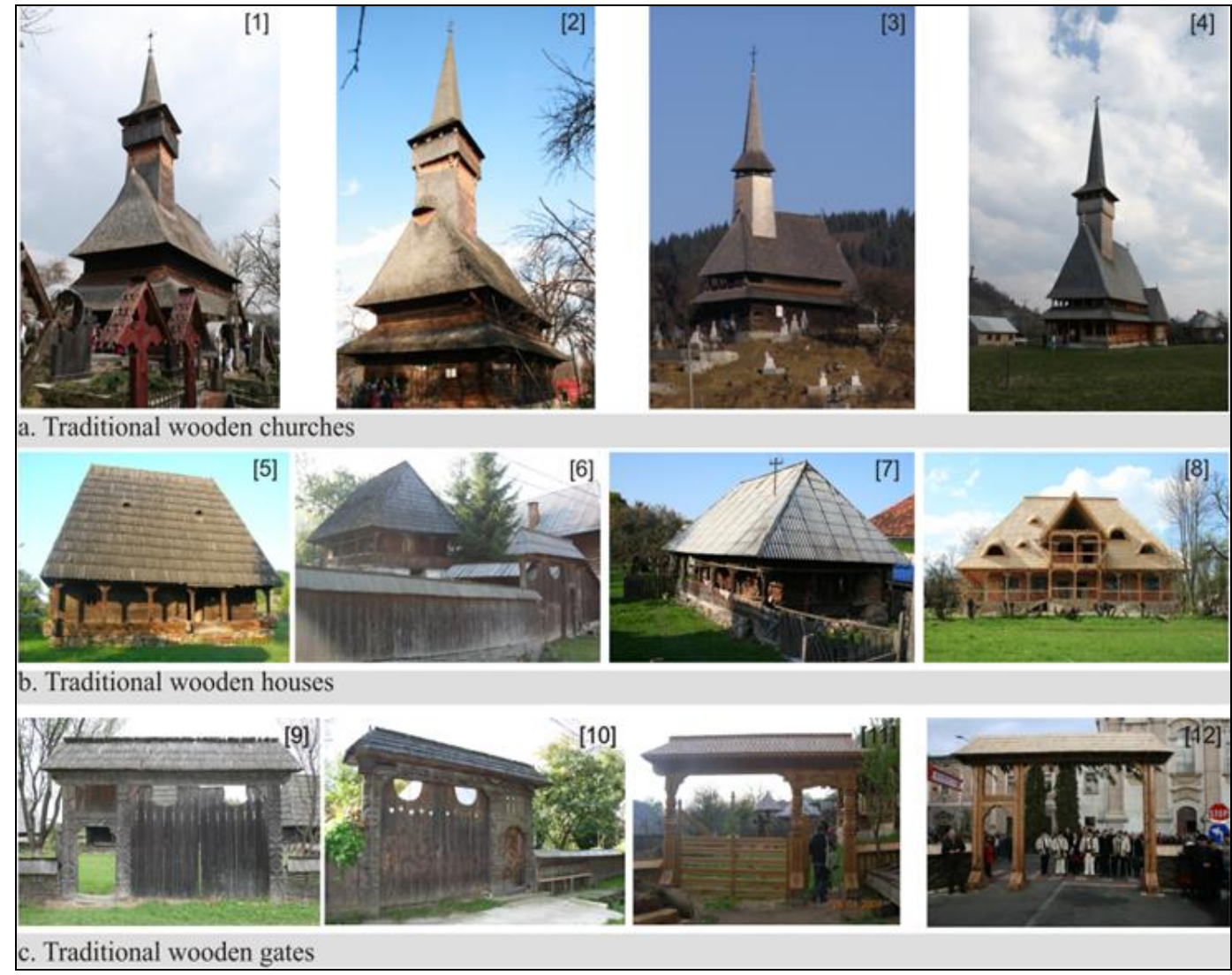

Figure 2. Illustrative examples of traditional wooden architecture in Maramures Land. [1] Ieud (1364); [2] Desesti (1770); [3] Rona de Jos (1665); [4] Ieud (2003); [5] Sarbi (1785, now in the Museum); [6] Budesti (1968, in situ); [7] Budesti (1974, altered, in situ); [8] Harnicesti (2008 , B\&B); [9] Barsana (1895, now in the Museum); [10] Sarbi (1975, in situ); [11] Barsana (2003, wood masters' gate); [12] Sighetu Marmatiei (2014, Marmatia Winter Festival)

Oak is the general choice for material, its features making the carving process durable and the structure stable (3-4m height and $4-5 \mathrm{~m}$ width). The vertical pillars are decorated with carvings having very strong symbolic value: sun rosettes, ropes, and geometric shapes in general, forming a composition named the tree of life (Biltiu, 2010: Dancus, 2010). The size and the richness of the carvings demonstrate the social status of 
the owner. Given the ephemeral nature of the material, wooden gates do not last over 50 years without restoration, although there are very old specimens on the ethnographic museums' premises (dating from the 19th century).

The gates are mostly perceived as artworks than heritage pieces, contributing to the general vernacular aspect of the village through their monumental characteristics demonstrating the artisanship of the masters. Their number is increasing, presently being inventoried more than 2000 pieces (fieldwork from 2010). The wooden church is an iconic feature of the regional identity; it is the logo on a wide range of tourism and place branding documents. Almost every community has at least one, 42 of them are listed monuments, eight on UNESCO's World Heritage List. In addition, 22 new churches built in the traditional Maramures style are located in the region, 15 in other parts of Romania and eight worldwide (USA, Canada, Japan, Switzerland and other). The planimetry of the churches in Maramures is uniform as concept, the same used in specific orthodox Romanian medieval architecture (Porumb, 1982). The silhouette of the wooden church given by the high arrow-shaped tower riding the roof conducted the specialists towards defining a separate Maramures style, also known as Romanian gothic (ICOMOS, 1999).

\section{CONSERVATION STATE AND DISCOURSE}

\section{Obvious decrease in number and diversity of traditional houses}

Peasant dwellings in the region feature the usual functional elements needed by a rural lifestyle. Long-standing researches conducted by ethnographers, museum professionals and scholars revealed that the wooden house has maintained the general aspect of the buildings from 18th and 19th century, with minor changes on the plan (Biltiu, 2010; Dancus, 2010; Herman \& Wendt, 2011; Ilieș et al., 2011; Petrescu, 1974). Ephemerality of the wood as construction material has oriented the specifics of restoration works towards the continuous replacement of the damaged parts, that is why in the 1970's very old beams, dating from the 17th century were discovered in an interior structure of a functional house (substantiated with dendrochronological measurements and original inscriptions (Dancus, 2010). Twenty-eight wooden houses dating from 1611-1870 AD have been restored and protected on the premises of the Ethnographic Museum in Sighetu Marmatiei (the central town of Maramures Land).

In situ, that old houses cannot be identified. Consequently, in 2007-2009 period, architects, geographers and tourism scholars conducted field researches which show that majority of the wooden dwellings date from the 20th century (Zaharie, 2009; Ilies et al., 2014). This detail generated large debates on the cultural value of the traditional house versus their market value. The traditional way of building of these simple homes is the result of an ancestral knowledge system, and because perpetuated in mountain areas it has become important to the substantiation of resilience thesis for rural communities (Ilies et al, 2010). Moreover, changes in the general aspect and continuity in terms of building techniques, demonstrate the responsive character of the shifts, the coping mechanisms to social, economic and political disturbances. The volume of the traditional wooden house increased due to growing needs of the families, the high roof flattened in some degree for economic reasons, wooden decorations were added on the facades and parts of the front terraces were closed by windows (Figure 3). In contrast, the old blockbau building system remained, due to its efficiency in certain environmental conditions. This is only the case of wooden structures, because these very same weather conditions generated a shift towards new building materials instead of the search for new heating solutions. The built landscape adopted the brick house, which in the early stage has had similar volumetry, shape and plan with the traditional wooden house. 


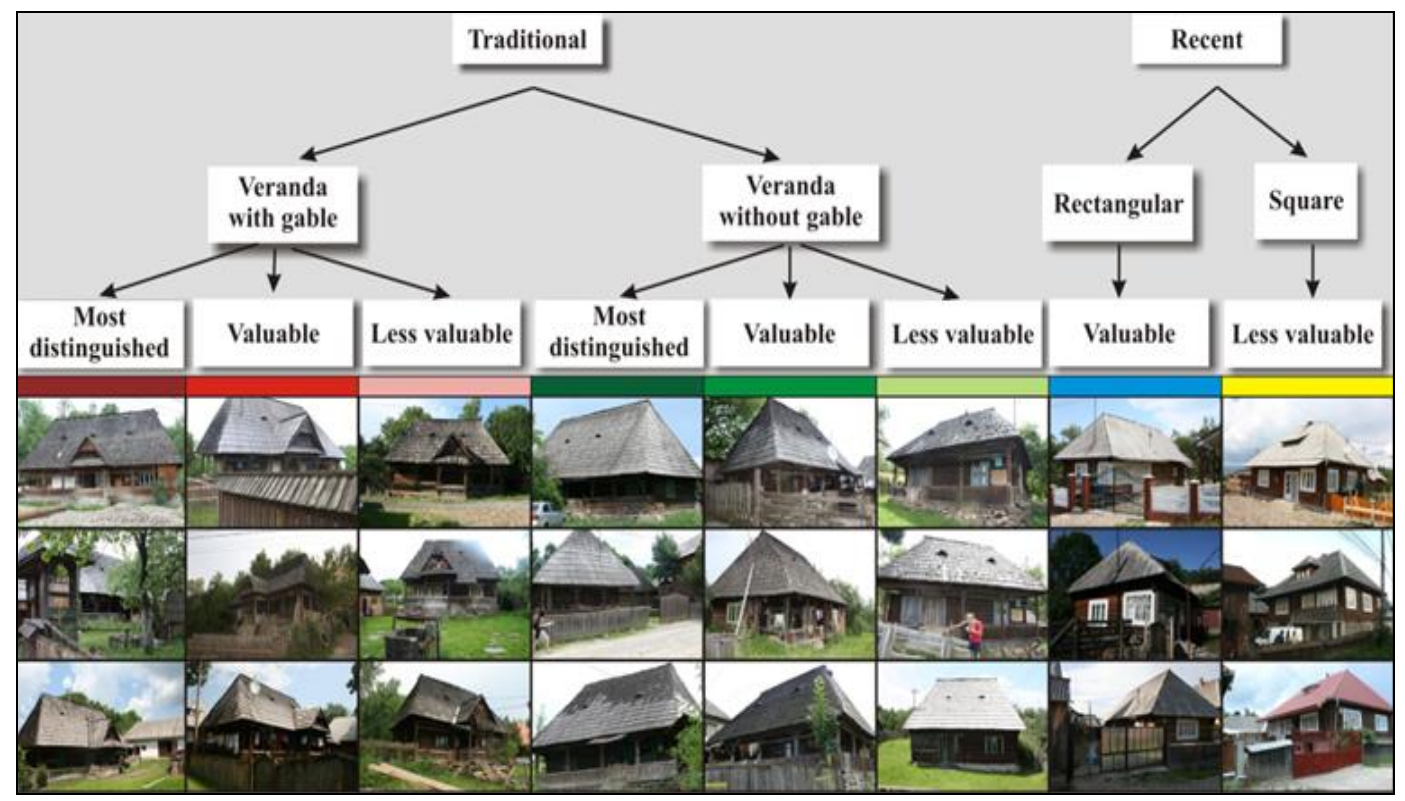

Figure 3. Classification of traditional houses in Maramures

Finally, the common home has suffered a second shift, generated by the periodical migration for work in other Romanian regions (before 1990) and towards western European countries and the subsequent acculturation of émigrés, importing new styles (after 2003). Therefore, the built landscape of Maramures is a mix of unregulated traditional buildings in wood and brick (Figure 4).

High cultural value houses tend to concentrate along secondary roads, isolation and accessibility being the most relevant cause for this situation. A decrease in number of these houses along the main communication axes generated at least two types of public discourse: (1) the traditional village is disappearing, and (2) the entire built landscape in rural areas with high cultural value is endangered. Meanwhile, cultural rural tourism has capitalized on heritage assets, vernacular architecture becoming the central core of the Maramures tourist brand, triggering the demand for accommodation with specific regional features, exterior as well as interior design. Bed-and-breakfasts extended their business by building in wood or restoring/adapting old houses to tourism.

Heritage protection policies were never tackling the traditional village in full, as national government fosters top-down approach but does not allocate budget. Communities have reacted with a bottom-up vision, considering the lack of public support for the national policies (Ilies \& Ilies, 2015; Ilies et al, 2010; Ilies et al, 2015).

\section{Traditional gates as art form are not endangered}

Traditional wooden gates are impressive structures that mark physically and symbolically the entrance into a special realm. The old gates coexist with the newly constructed, their number being significantly higher than that of the traditional houses, due to the habit of installing them in front of a great variety of properties. Old gates, in terms of artistic features and age, similar to the gates conserved in the open-air museum, are on a descending trend. In contrast, new monumental gates are installed continuously, in a more elaborated style, featuring rich carvings and several solid pillars. From artistic vantage point, they are at the margin between traditional and kitsch. 
What Future for the Land of the Wooden Civilisation?

Vernacular Architecture from Maramures as subject of a long standing debate

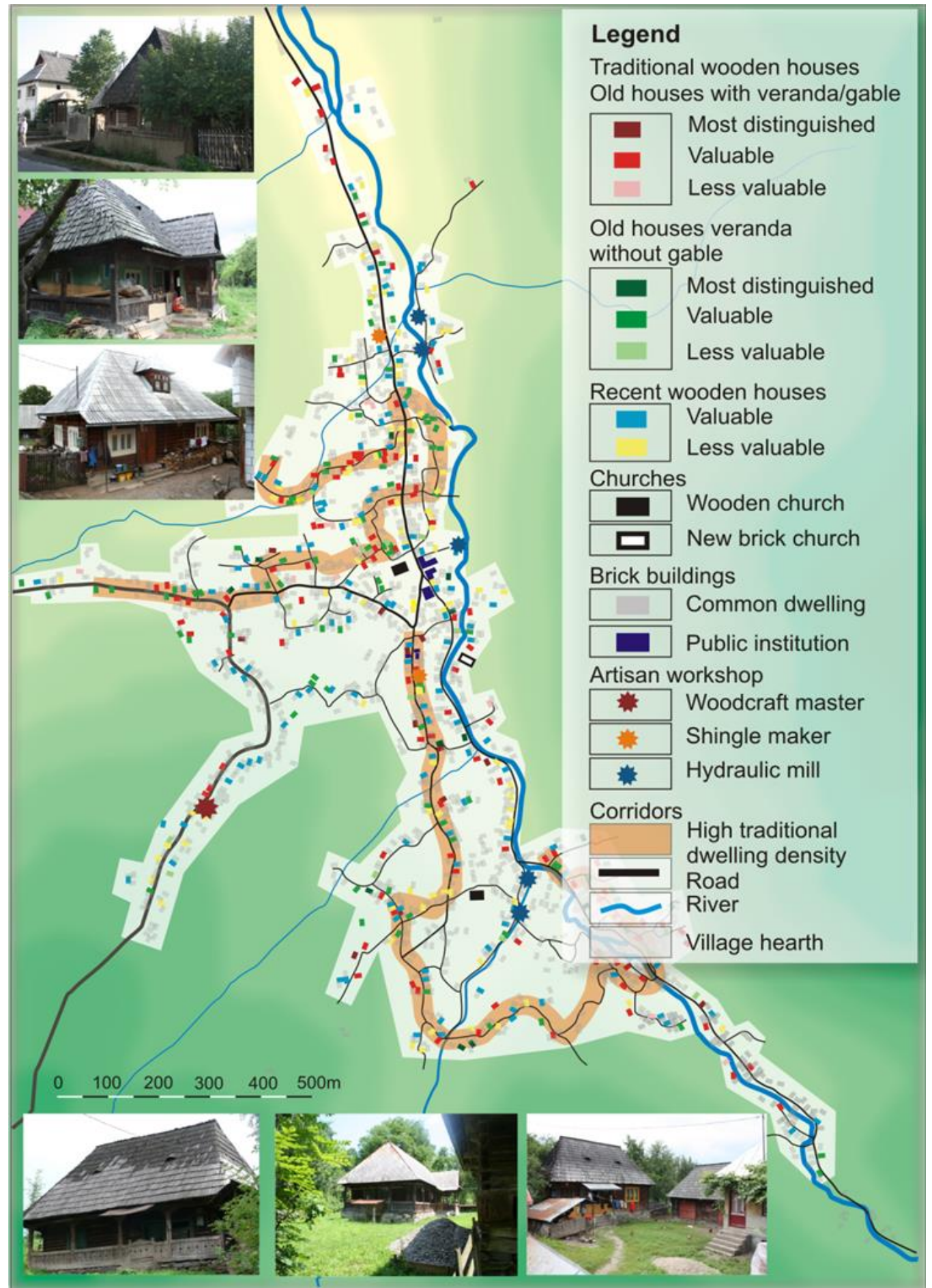

Figure 4. Budesti village: conservation state of the vernacular architecture.

(Source: adapted from Ilies, Ilies \& Hotea, 2010) 
On the other hand, building a comprehensive database containing the gates is a difficult task, given the momentum. Spatial data show a higher density in the villages that harbour wood master workshops: Barsana, Desesti, Vadu Izei (see also Figure 2).

Symbolic gates are evenly dispersed, in all villages and towns of Maramures. In conclusion, preservation issues focus mostly on the type of approach, than on an extensive plan. The views employ both the traditionalist side, which states that certain aesthetic norms should be followed, inspired from the 1970-1980 masters' portfolio and the golden ration, and the functional side, which values innovation.

\section{Wooden churches as Romanian identity marker}

Three types of wooden churches are relevant in Maramures, with different protection needs: 'A list' heritage monuments, included on UNESCO's World Heritage List, along with national patrimony properties and modern day buildings in Maramures style, without listing. Cultural and spiritual norms prohibit the demolition of the churches; therefore, communities donated their former church to other less fortunate villages before constructing a more suitable one. This is why the history of restoration and other works is difficult to trace and the metaphor 'traveling churches' gained shape in the media (Babos, 2004). There is an important number of wooden churches built before 1717: Ieud (1364), Bârsana (1380), Breb (1531), Sat Şugatag (1642), Budeşti (1643), Mănăstirea (1653), Valea Stejarului (1600), Rozavlea (1661), Strâmtura (1661), Sârbi (1665) according to Toth (1969), Dancus (2010), and Ilies et al., (2016) .

Other churches were rebuilt after the great tartar invasion on the same plan. Dendrochronology studies revealed newer construction periods than known from archives, sparkling debate on the real age of older churches (Dezsi et al., 2014; Baias et al., 2016, Gozner et al., 2016). Religious sermon is conducted only annually in the protected churches, due to the heritage protection plan aligned to the UNESCO guidelines, as highlighted by ICOMOS in the 1999 report. It was a serious issue with the administrative capacity of the sites, at that time, situation solved later by the county council and its heritage protection department (www.cjmm.ro).

\section{Public discourse on vernacular architecture from Maramures}

Previous sections of this study highlighted the concept of "the land of the wooden civilisation" from heritage perspective. In order to complement the analysis, the role of the public discourse on the matter is decoded as core feature of the traditional village: rural culture forged on wood and built environment dominated by timberworks with incorporated special knowledge. This type of regional discourse dates back in the 1970s, when ethnographers started to communicate the threats on the rural lifestyle: industrialisation, rural - urban migration and modernisation in general (Dancus, 2010). Large open-air museums across Romania were organised to preserve the heritage, replacing small local collections from the interwar period. Additionally, several popular folk-life festivals capitalised on the traditional holydays: spring events linked to the agrarian calendar, summer meetings in high mountains and market places and disguised winter Christmas customs. The latter in Sighetu Marmatiei, was so popular that it has remained unattained for 48 years, until today, featuring wooden decor and allegoric carriages linked to woodcrafts (see also Figure 2).

Political changes in the 1990s (downfall of the communist regime) aggravated the social issues of Romanian rural communities, triggering a descendent demographic trend, population aging and periodical migration for international work (INSSE, 2016). Meanwhile, the property regime on the forest changed from public to private, organised in compossessorates (a medieval co-ownership on the forest) facilitating deforestation. This made the wood harvesting under legal conditions very difficult and expensive. 
Therefore, the rhythm of building in wood decreased leaving the traditional landscape in a neglected state and in silence. Scholars and museum practitioners continued to write about the cultural values of the wooden architecture, with important steps towards protection, and ultimately, UNESCO was perceived as the only effective structure that could help with this matter (Cristea \& Dancus, 2000).

Another turning point, around the year 2000, was the acknowledgement of the market value of the wooden houses, this time as reclaimed wood. Local entrepreneurs entered a Swiss network of recycled materials, which started to purchase old oak houses for this purpose. Given the low value of a standing wooden house (300o - 4000EUR) an unprecedented demolition process was in place, starting with the buildings along the main communication axes. The process did not evolve unnoticed, NGOs and local stakeholders published editorials in media, implemented educational projects in order to minimise the impact of this loss. In addition, research teams focused on projects to substantiate scientifically the phenomenon during 2006-2009.

In 2008, the conservation state of the vernacular architecture reached into public discourse, as statement it was included in the text of local development strategies as priority. As formulated, the preservation plans have been inspired by the nature preservation guidelines, asking for a higher regulation sets for owners and architects. General themes of this new discourse are: them,

(1) the need to protect acknowledged cultural assets, vernacular architecture among

(2) improvement of the communication strategies regarding these values, through tourist information centres,

(3) involvement of the younger generation in the process, specially organised events, and

(4) enforcement of the existing urbanism regulations for new buildings.

Table 1. Priorities and operational objectives for the local

development strategy of LAG Mara-Gutai (Data source: UNSG, 2016)

\begin{tabular}{|c|c|c|}
\hline PRIORITY & ACTIONS & DISCOURSE \\
\hline \multirow{4}{*}{$\begin{array}{l}\text { Raising the } \\
\text { attractiveness } \\
\text { of the territory }\end{array}$} & $\begin{array}{l}\text { Supporting cultural } \\
\text { activities and events }\end{array}$ & $\begin{array}{l}\text { Authentic cultural products associated to the rural } \\
\text { tourism activities in the area }\end{array}$ \\
\hline & $\begin{array}{l}\text { Developing the promotion } \\
\text { and communication tools }\end{array}$ & $\begin{array}{l}\text { Website design and layout with visual elements derived } \\
\text { from traditional woodcarving, textiles and painting. }\end{array}$ \\
\hline & $\begin{array}{l}\text { Renovation of cultural } \\
\text { infrastructure }\end{array}$ & $\begin{array}{l}\text { Authentic folk costumes reinforce the pride of } \\
\text { wearing them and re-launch the production. }\end{array}$ \\
\hline & $\begin{array}{l}\text { Valorisation of natural } \\
\text { and cultural heritage }\end{array}$ & $\begin{array}{l}\text { Support authentic features in the architecture of } \\
\text { the future tourist infrastructure; Respect the } \\
\text { tourist carrying capacity of the protected areas }\end{array}$ \\
\hline \multirow{3}{*}{$\begin{array}{l}\text { Increasing } \\
\text { competitiveness } \\
\text { and economic } \\
\text { viability }\end{array}$} & $\begin{array}{l}\text { Diversification of } \\
\text { local produce offer }\end{array}$ & $\begin{array}{l}\text { Encouraging local groups to form cooperatives } \\
\text { and to concentrate on local produce }\end{array}$ \\
\hline & $\begin{array}{l}\text { Enhancing the storage } \\
\text { and selling capacity } \\
\text { for local produce }\end{array}$ & Building markets and storages \\
\hline & $\begin{array}{l}\text { Encouraging small farms } \\
\text { to enter the produce market }\end{array}$ & Support small farms with funding and logistics \\
\hline \multirow{2}{*}{$\begin{array}{l}\text { Developing the } \\
\text { cooperation and } \\
\text { management } \\
\text { capacity }\end{array}$} & Partnership development & $\begin{array}{l}\text { Common tourist attractions and infrastructure } \\
\text { promotion }\end{array}$ \\
\hline & Local management abilities & Good project team \\
\hline
\end{tabular}


After a very long debate, the county council implemented only one relevant project, concerning the tourism integration of the UNESCO churches across the region, between 2010 and 2016. At local level, four of well-defined projects on the traditional architecture attracted 50,000EUR funding for LAG Mara - Gutai. (Table 1).

\section{CASE-STUDY: UNESCO}

The listing process of Maramures wooden churches on the World Heritage list stretched on a five-year period, while Romania was struggling with unprecedented social and economic changes due to the post-socialism transition (Ianos, 1996). The communities with a church on this list (Barsana, Budesti, Ieud, Deseti and Poienile Izei) extended the guidelines into their own sustainable development plan, but funding was insufficient. In addition, the villages holding a wooden church similar in age and cultural value to the listed ones have been inspired by these guidelines, hoping for a comparable attention on heritage protection.

„The Maramures wooden churches represent a selection of eight outstanding examples of different architectural solutions from different periods and areas. They provide a vivid picture of the variety of design and craftsmanship expressed by narrow but high timber constructions with their characteristic tall, slim clock towers at the western end of the building, single or double roofed and covered by shingles. As such, they are a particular vernacular expression of the cultural landscape of that mountainous area of northern Romania."(ICOMOS, 1999).

Table 2. Comparative analysis on the outlined priorities and discourse on local vernacular architecture

\begin{tabular}{|l|l|l|l|}
\hline \multicolumn{1}{|c|}{ Measures } & \multicolumn{1}{c|}{ Priorities } & \multicolumn{1}{c|}{ UNESCO's discourse } & LAG Mara-Gutai discourse \\
\hline $\begin{array}{l}\text { Development } \\
\text { planning } \\
\text { measures }\end{array}$ & $\begin{array}{l}\text { National } \\
\text { framework }\end{array}$ & $\begin{array}{l}\text { National division signing } \\
\text { every relevant agreement on } \\
\text { cultural heritage preservation }\end{array}$ & $\begin{array}{l}\text { Aligning to the LEADER+ } \\
\text { initiative on rural } \\
\text { development }\end{array}$ \\
\hline $\begin{array}{l}\text { Measures aimed } \\
\text { at achieving } \\
\text { economic, social, } \\
\text { cultural } \\
\text { or environmental } \\
\text { outcomes }\end{array}$ & $\begin{array}{l}\text { Supporting the cultural and } \\
\text { creative sector } \\
\text { Suptainable } \\
\text { and } \\
\text { resilience } \\
\text { business incubators for } \\
\text { SMEs in the cultural sector. } \\
\text { Marketing and promotion } \\
\text { Training and skills }\end{array}$ & $\begin{array}{l}\text { Supporting authentic } \\
\text { cultural creative sector; } \\
\text { Supporting small groups of } \\
\text { tourism and related SMEs } \\
\text { Promoting non-formal } \\
\text { education and apprentice } \\
\text { /shadowing classes } \\
\text { Suppont }\end{array}$ \\
\hline $\begin{array}{l}\text { Supporting cultural } \\
\text { at achieving } \\
\text { regional equity } \\
\text { institutions }\end{array}$ & $\begin{array}{l}\text { Polycentric } \\
\text { approach }\end{array}$ & $\begin{array}{l}\text { Top - down heritage } \\
\text { preservation guidelines } \\
\text { according to the European } \\
\text { approach on cultural value }\end{array}$ & $\begin{array}{l}\text { Bottom-up strategies are } \\
\text { best adapted to the } \\
\text { culturally sustainable } \\
\text { community }\end{array}$ \\
\hline
\end{tabular}

The selection process of only eight churches from a group of twenty-eight was a difficult process; the debates sparkled then may be heard even after twenty years. Features as 'the interchange of Orthodox religious traditions with Gothic influences' or 'a high level of artistic maturity and craft skills' (ICOMOS, 1999) are representative for almost every traditional wooden church in Maramures, old or new, Orthodox or Greek- 
Catholic. This aligns with the theoretical framework outlined by Di Giovine (2008) as museological procedure of place making without the traditional recontextualisation (Table 2). Although, wooden churches usually do not belong in museums, there are several specimens across Romania in Sighetu Marmatiei, Cluj Napoca, Sibiu and Bucharest, forming a larger base for cultural value assessment of the entire group in Maramures.

For the listed properties, UNESCO has been a quality label in respect with cultural tourism branding, leaving out of the main flow the unlisted wooden churches. It signifies the need of Romania, following the example of other European countries, to present its history through tangible heritage, its Dacian-Roman as well as Orthodox identity, and create new stories and new post-communist image with a clearly diversified nation of various ethnicities and religions (Kocoji, 2015). The relationship between heritage protection and cultural tourism is that of a 'working relationship' described by McKercher, B, Du Cross H (2002) as "realisation of common needs and interest, begin dialogue and work to ensure that both interests are satisfied". Tourism branding strategies constantly capitalise on the universalism of the vernacular architecture from Maramures Land, the interpretation and translation into Romanian culture of this status is working well because the properties are neither in an advanced stage of degradation nor in danger (Beck, 2016; Labadi, 2013). Nevertheless, there is a need for further research on the carrying capacity of each protected site, the tourist number limitations are not real, nor the control on the risk factors for the interiors of these churches.

As Throsby, D. (2015) argued sustainable development strategies underline the "formulation of strategies to achieve culturally sustainable development, a concept that brings together the cultural and economic dimensions of development in a framework emphasizing growth, equity and cultural integrity in the development process".

\section{CONCLUSION}

Analysis revealed that the great debates on the endangered status of the rural vernacular architecture have focused only on the overall landscape, from a superficial perspective. More profound issues as the perceived value of the wooden dwellings, the most effective ways of adapting it to the contemporary lifestyle, resilience, sustainable usage of heritage tourist sites, etc. are transferred to administrative levels. A bottom-up approach and the involvement of academic research have had a great role in coordinating these strategies. Refined discourses regarding the wooden architecture in Maramures acted as funding triggers. In addition, innovative architectural concepts inspired by traditional wooden buildings are crucial for the future of the Land.

\section{REFERENCES}

Babos, A. (2004). Tracing a Sacred Building Tradition. Wooden Churches, Carpenters and Founders in Maramures until the Turn of the 18th Century AD. Lund University Press, Lund. http://lup.lub.lu.se/search/record/21535 (accessed 25 July 2015).

Baias, Ș., Gozner, M., Herman, G.H., \& Măduța, F.M. (2015). Typology of wooden churches in the drainage basins of Mureș and Arieș, Alba County. Analele Universităţii din Oradea, Seria Geografie, Tom XXV, Nr. 2/2015 (December), Editura Universităţii din Oradea;

Beck, W.(2016). Narratives of World Heritage in Travel Guidebooks. International Journal of Heritage Studies; 12(6): pp. 521- 535 .

Biltiu, P. (2010). Arta lemnului in Maramures [Wood art in Maramures]. Eurotip: Baia Mare.

Brunskill, R.W. (2000). Illustrated Handbook of Vernacular Architecture, 4th ed. London: Faber and Faber.

Claval P. (1993). Initiation a la geographie regionale [Initiation in tourism geography]. Nathan: Paris.

Cocean, P. (1997). Ţara (The Land) - a typical geographical region of Romania. Revue Roumain de Geographie; (41): 156-169. 
Cristea, G., \& Dancus, M. (200o). Maramures -un muzeu viu in centrul Europei [Maramures- a live museum in the center of Europe]. Ed. Fundatiei Culturale Romane:Bucuresti.

Dancus, M. (2010). Vernacular architecture from Maramures. Dacia: Cluj Napoca.

Dezsi, S., Rusu, R., Ilies, M., Ilies, G., Badarau, S., \& Rosian, G. (2014). The Role of Rural Tourism in the Social and Economic Revitalisation of Lapus Land (Maramures County, Romania), Proceedings of the 14th SGEM GeoConference on Ecology, Economics, Education and Legislation, 2, pp. 783-790.

Di Giovine, M.A. (2008). The heritage-scape: UNESCO, world heritage, and tourism. Rowman and Littlefield Publishers: Lanham.

Ianos, I. (1996). The changing Romanian village: The case of Semlac in Arad County, Romania. GeoJournal; 38(2), pp:175-179.

Gozner, M., Josan, I., Baias, Ș., \& Măduta, F.M. (2016). The Religious Attractions - An Expression of Authenticity in the Territorial System Albac - Arieşeni and Alba County (Romania). GeoJournal of Tourism and Geosites, Year VIII, Volume 15, Oradea-Gdansk, Romania-Poland, Editura Universităţii din Oradea.

Herman, G. V., \& Wendt, J. (2011). Development and Promotion of Tourism, an Extra Chance in Maintaining and Asserting the Identity and Specificity of Oaş Land. GeoJournal of Tourism and Geosites, 1(7), 87-95.

Ilies, A., Wendt, J., Ilies, D., Josan, I., \& Herman, G. (2011). The Romanian Rural Architectural Heritage from Maramureş Land-Personality, Distinctiveness and Protection. Studia Universitatis BabesBolyai, Geographia, (2), 187-196.

Ilies, A., Wendt, J.A., Ilies, D.C., Herman, G.V., Ilies, M., \& Deac, A.L. (2016). The patrimony of wooden churches, built between 1531 and 2015, in the Land of Maramures, Romania. Journal of Maps ; 12(Suppl. 1); pp:597-602.

Ilies, G., Ilies, M., \& Hotea, M. (2010). Budesti. Maramures. In G. Ilies (Ed.), Modele ale specificitatii regionale.Suport pentru strategiile de valorificare turistica a satului traditional romanesc [Regional specificity models. Handbook for rural tourismstrategies in Romania's traditional villages]. (pp. 99-115). Cluj Napoca: Presa Universitara Clujeana.

Ilies, M., \& Ilies, G. (2015). Identity based geo-and tourism branding strategies derived from rural Maramures Land. GeoJournal of Tourism and Geosites; 16(2); pp:179-186.

Ilies, M., Ilies, G., \& Hotea, M. (2014). Studii asupra zonei "Grupul de Actiune Locala Mara - Gutai". [Studies on the zone of the Local Action Group Mara - Gutai]. Presa Universtara Clujeana: Cluj Napoca.

Kocoji, E. (2015). Monuments of Romanian Tangible Culture Inscribed on the UNESCO World Heritage List (a Short Presentation). Kocoj, E., Gawel, L. (eds). Faces of Identity and Memory. The Cultural Heritage of Central and Eastern Europe (Managing and Case Studies). Kraków: Wydawnictwo UJ; pp. 11-34.

Labadi, S.( 2013). UNESCO, cultural heritage, and outstanding universal value: Value-based analyses of the World Heritage and Intangible Cultural Heritage Conventions. Rowman and Littlefield Publishers: Lanham.

McKercher, B., \& Du Cross, H. (2002). Cultural Tourism: The Partnership between Tourism and Cultural Heritage Management. Routledge: London and New York.

Petrescu, P. (1974). Arhitectura de lemn taraneasca de lemn din Romania [Wooden peasant architecture in Romania]. Meridiane; Bucuresti.

Porumb, M. (1982). Monumente istorice si de arta religioasa din Arhiepiscopia Vadului, Feleacului si Clujului [Historic monuments and of religious art in Vadului, Feleacului and Clujului Archiediocese]. Dacia: Cluj Napoca.

Throsby, D. (2015). Culture in sustainable development in Reshaping cultural policies in Convention Global Report A Decade Promoting the Diversity of Cultural Expressions for Development. UNESCO; http://unesdoc.unesco.org/images/o024/o02428/242866e.pdf (accessed 10 September 2016).

Toth, B. (1969). Metode in cercetarea tipologica si stilistica a arhitecturii populare [Research methods regarding the rural architecture]. Satu Mare ; 14(1), pp:203-220.

Zaharie, L. (2009). Programul de protectie pentru peisajului construit în Maramures [Programme for the protection of built lanscape in Maramures]. OAR: Baia Mare.

*** International Commission on Monuments. (ICOMOS). (1999). Evaluations Of Cultural Properties. http://whc.unesco.org/en (accessed 21 November 2016).

*** National Institute of Statistics (INSSE). (2016). TEMPO - time series, matrix from Labour force, Population and its demographic structure and Tourism. Bucuresti; http://statistici.insse.ro (accessed 10 October 2016).

*** United Nations. (UNSG). (2016). Sustainable mountain development . Report of the Secretary-General;. www.un.org/en/ga/second/71/documentslist.shtml (accessed o9 September 2016).

www.cjmm.ro Maramures County Council. Maramures County. (accessed o7 December 2016).

Submitted:

20.04.2018
Revised:

10.09.2018
Accepted and published online 14.09.2018 